\title{
On place, becoming, and advocacy
}

\author{
Lourdes Torres ${ }^{1}$
}

Published online: 5 November 2018

(c) Springer Nature Limited 2018

The articles in this issue center the importance of place in the unfolding and shifting dimensions of racial identifications, advocacy and voice. Cecilia Márquez and Jennifer Leeman lead this issue with articles on "becoming" that illustrate the dynamics of place in the making of race. The census is one pivotal location wherein people are explicitly prompted to declare their ethnoracial identity. In her contribution, Leeman examines how racial identities and racial discourse are produced and reproduced in the US Census, specifically in the census interview. Using a sociolinguistics approach, she unpacks how ethnoracial classification is taken up, challenged and negotiated in the exchange between census-takers and citizens. Her nuanced analysis demonstrates that identity is intersubjectively co-constructed in discourse and reaffirms the idea that ethnoracial categories are dynamic and situational. In fact, as Leeman states, "censuses capture only one moment of ethnoracial identity" given that "identity is subject to temporal, contextual, and interactional flux."

Cecilia Márquez also interrogates the construction of racialized categories in "Becoming Pedro: 'Playing Mexican' at South of the Border." While recent scholarship highlights how Latino migration has transformed the South, Márquez focuses on the history of South of the Border, which became a well-known themed rest stop in South Carolina in the 1950s. She finds that even before large-scale migration to the "Nuevo South," white southerners were already generating and propagating racial fictions about Mexicanness. Her cultural studies analysis demonstrates how, in response to rising anxiety concerning postwar transformations and challenges to Jim Crow rule, white southerners produced regionally specific, stereotypical representations about Mexicans. As Márquez argues, this fascinating history "helps us better understand the evolving nature of white supremacy and its relationship to fantasies about Latino/as."

Lourdes Torres

ltorres@depaul.edu

1 DePaul University, Chicago, IL, USA 
In his contribution on an unexpected site of advocacy, Raúl Necochea López sheds light on the genesis of the Ventanilla de Salud (VdS) program, a rare endeavor by the Mexican government to support the health of its diaspora via its consulates in the United States. The VdS program intended to provide Mexican citizens living in the United States and Canada information about local health services, referrals, and counseling. This origin story is particularly interesting, since it highlights the dogged tenacity of US-based migrant advocacy organizations and philanthropies to persuade Mexican officials to open up consular space for the purpose of increasing access to health care. This goal was far removed from the usual governmental bureaucracy typical of consulates. Necochea López outlines exactly how nongovernmental actors propelled this significant change in Mexican foreign policy which led to noteworthy diplomatic involvement in migrant health advocacy and activism.

Next, Mónica González Ybarra unpacks the genesis of activism and voice in the lives of Latinx undocumented youth and youth of mixed status who live in Comunidad Miravalle, a migrant housing complex in the western Rocky Mountain region. Guided by Gloria Anzaldúa's conceptualization of nepantla, and using pláticas as a methodological and pedagogical tool, González Ybarra describes how youth share their evolving reflections on the contradictory discourses of illegality, migrant labor, and citizenship that profoundly condition their lives. Together they think through competing discourses surrounding immigration and what it means to belong in the United States today. She is very much interested in holding up these youth as knowledge producers who, through their voices, develop and transform their lives and their politics through intense community dialogues.

In addition to these articles, this issue features an expanded Vivencias section. Earlier this year, we invited "reports from the field" that highlight the work that scholar-activists are undertaking or witnessing in response to the current political climate. We are interested in creating a vibrant space within our pages where scholar-activists can consider how Latinos within and outside of academia are responding to the barrage of hateful rhetoric that demonizes Latinos and increases the threat of violence against our communities, as well as the steady stream of policy changes that disenfranchise Latinos. I am happy to share with you five stimulating Vivencias that will enliven this conversation.

In her provocative contribution, Lilia Fernández cautions us against being so consumed with the current administration's almost daily insults and lies that we are distracted from the big picture-specifically, the dangerous neoliberal economic policies conservatives are putting into place that will have long-term effects on the well-being of Latinos and other marginalized groups. She reminds us that, although the rhetorical transgressions are hard to ignore, we cannot lose sight of the imperative to focus on economic inequities and disparities that profoundly affect our communities.

Michael De Anda Muñiz describes his experience teaching Latino studies inside a maximum-security prison as a project to fight the dehumanization of prisoners. He details how Latino studies can build solidarity among Latino and black incarcerated persons and help them understand that they are part of a historical, intellectual and political community. Scholarly and creative work produced behind bars is exhibited 
in spaces and galleries outside the prison and thus extends those voices beyond the prison walls.

Our last three Vivencias were inspired by the devastating hurricane that struck Puerto Rico a year ago. Each piece attests to the commitment of Puerto Ricans on the Island and in the diaspora to rebuild their country, and to their understanding that it is efforts from the community for the community that will make the difference. Roberto Vélez-Vélez and Jacqueline Villarrubia-Mendoza provide an inspiring report on the Centros de Apoyo Mutuo that emerged after the hurricane. They document how Puerto Ricans created these Centros to help themselves, through pooling their resources and using their ingenuity, well aware that help from governments and foundations is inadequate and often comes with strings attached that end up creating dependency rather than autonomy. Marisa Alicea and Maura Toro-Morn detail how Puerto Rican Chicago immediately responded to the Island's needs by mobilizing the local Puerto Rican community's resources. This effort developed organically from transnational collaborations that have been in place for more than twenty years. Alicea and Toro-Morn show that the diaspora's response continues to unfold in a variety of ways, including through the arts and through advocacy and protest actions on behalf of Puerto Rico. Finally, we are honored to share Angelo Falcon's last opinion piece (see the In Memoriam published in Latino Studies 16.2), which makes a compelling case for the necessity of reparations for Puerto Rico, given its centurieslong history of colonialism and exploitation.

We look forward to your responses to these essays and the addition of your voice to this conversation. 